\title{
Subjectivity, Individuality and Abjection in Kate Chopin's The Awakening
}

\author{
Kamelia Telebian Sedehi (Corresponding author) \\ Faculty of Modern Languages and Communication, Universiti Putra Malaysia \\ Nur Fatin Syuhada Ahmad Jafni \\ Faculty of Modern Languages and Communication, Universiti Putra Malaysia \\ Wan Roselezam Wan Yahya \\ Faculty of Modern Languages and Communication, Universiti Putra Malaysia
}

Received: 15-07-2015

doi:10.7575/aiac.ijclts.v.3n.4p.14
Accepted: 23-08- 2015

Published: 31-10- 2015

\begin{abstract}
Julia Kristeva's concept of abjection deals with how the subject intends to gain his/her subjectivity by rejecting the things which are not considered part of himself/herself. In Kate Chopin's The Awakening (1899), the protagonist, Edna Pontellier, is portrayed as a married woman but one who has romantic affairs with other men. Deemed unthinkable, Edna's desire and search for true love is seen as an act of defiance by the society in which she lives. Edna's life's boundaries are blurred and confused by her ambiguous actions, a display of her attempt at abjection. By applying textual analysis as our methodology, this research aims to delve into how Edna fights for her individuality and sense of self. As a result, the analyses are divided into two parts, namely, Search for Subjectivity and Individuality and Edna Pontellier's Awakened Individuality. Besides, the reaction of patriarchal society towards Edna's search for independent subjectivity is scrutinised as it greatly affects Edna's life. By applying Kristeva's abjection to Chopin's The Awakening, the current article intends to focus on Edna's attempt at self-realization.
\end{abstract}

Keywords: Abjection, Subjectivity, Self and Other, Self-realzation

\section{Preamble}

Kate Chopin's The Awakening was originally entitled The Solitary Soul and banned from the shelves of local libraries on its release. This was mainly, because of its theme of the protagonist's act of defiance, rejecting the social norms as she abandons her husband and family in her 'selfish' quest for self-fulfilment, this theme being deemed controversial for its immorality. The rebuke from society was so harsh that it stopped Kate Chopin pursuing her path as a novelist.

Edna Pontellier is the wife of Mr Pontellier but had tendency towards Robert Lebrun, and later had an affair with Alcée Arobin. Her attitudes towards all three men are quite different and depend on how she feels towards them. Her behaviour dictates her search for love. As Anneta Greenlee puts it, the protagonist desires "perfect love" (2007, p. iv). However, flitting from one man to another, Edna fails to find the desired love. With Mr Pontellier, she submits to him as a wife; as for Robert Lebrun, she was turned down because of Robert's reluctance to break the social norms; and Arobin is nothing more than a man to distract her from her abysmal relationships with Mr. Pontellier and Robert. Her fluid transition from one man to another can be seen as an attempt to keep searching for the right and perfect love; but, the

[a]bsolute desire, which admits to no compromise, is continually frustrated by experience, leading some protagonists [Edna Pontellier] to despair and withdrawal from life. (Greenlee, 2007, p. iv)

Touching on the topic of a "withdrawal from life", Edna's decision at the end of the novel has been widely discussed. There have been debates as to whether Edna eventually committed suicide or if there is a twist such that Edna returns to the shore. However, this speculation about alternative endings will not be highlighted here as that requires a separate research approach. But the significance underlying Edna's decision will not be overlooked. Edna's suicide attempt projects two ambivalent views: 1) Edna's surrender, or 2) Edna's liberty.

With regard to the first point, Edna's decision to end her life is greatly influenced by the pressure put on her by society's expectations. Tamara Powell, in her research, argues that the superego has scarred her and ultimately affected her reasoning, thus preventing her from being able to withstand the pressure. "Edna is described as "not a motherwoman" (8), and this description is helpful in understanding why Edna eventually must end her life" (2009, p. 277). In addition, the suicide also marks Edna being at her wits' end. Without any tolerance, Edna cannot abide the thought of 
being scrutinized by society or judged by her husband or her lovers, and so her choice to end her life symbolises "a strong statement: woman is trapped, there is no way out" (Parvulescu, 2005, p. 487).

Yet, Edna's suicide can also be seen as a form of subtle, almost secretive, liberty. In contrast to the first point, which takes note of Edna being submissive and choosing to end her life due to society's pressure, this second point opts to support Edna's choice.

While the $19^{\text {th }}$ century's femme "encounters terror, ambiguity, and seductiveness and stays safely ashore"; Chopin's Edna "leaves the shore and swims to meet them" (Bradley, 2005, p. 58), thus illustrating that Edna Pontellier's something is neither a moral punishment nor a feminine escape, but a feminist triumph. (Bai, 2014, p. 848)

And thus her suicide is seen as a moment of awakening, as well, as she is "now ready to confront death, to face death. Such is the nature of her awakening: that is awakening-unto-death" (Parvulescu, 2005, p. 486).

In seeking to understand Edna through her antics and behaviour, we agree with the following motion:

In general, her [Edna] depressive thoughts seem to subside only when Edna feels she is in control of both her body and the men in her life... the thought of not being in control of one's own body or choices would be frightening for anyone, but for someone who has been physically violated, the fear of losing such control could be devastating, even life-threatening. (Platizky, 1995, p. 100)

A decade later, Parvulesco comes out and comments favourably on the effects of power on Edna's behaviour:

It would be insufficient to say that say that what Edna wants is power, even if that only means power over herself. Because power too finds its way in the novel through a language of intoxification. The moment of power is the moment of learning to swim... The narcotic of power stops Edna from being anguish, from going toward the ultimate experience that will be pushed to its limit only at the end of the novel. (2005, p. 481-2)

And her choice to venture into the sea is seen as her moment of awakening, "[t]he moment Edna is ready to embrace the unknown of the sea, will be identified as the promise of this awakening" (Parvulescu, 2005, p. 477). The following will elaborate on the concept which will be applied to The Awakening.

\section{Julia Kristeva and Abjection}

Julia Kristeva considers abjection as the state in which the subject rejects whatever is other to oneself in order to create "I". The baby considers that his mother and his body are one; but as he sees his image in the mirror, he starts to perceive that he is separate from his mother. At this stage, the infant starts to coo and babble. The infant gains his sense of unity in the mirror stage as he attempts to unify himself and the image in the mirror in order to develop his identity. As he unifies himself and the image, he seeks to separate himself from others to complete the process of unification and develop the borders of "I". Through this process of abjection, the child expels whatever is not part of himself.

The child expels, rejects, excludes and spits out whatever is not part of him. Kristeva defines the abject as:

Something rejected from which one does not part, from which one does not protect oneself as from an object. Imaginary uncanniness and real threat, it beckons to us and ends up engulfing us. (Kristeva 4)

As the mother is not part of the borders of the child, she is rejected. The mother's body is rejected as "the abject would thus be the 'object' of primal repression" (Kristeva 12). The abject object is not repressed as it does not totally disappear from consciousness. This abject object can be the rejection of social norms which restrict a person, social bounds such as marriage, family relationships or any other sense of responsibility towards others which prevents the subject from having his own authentic self. In fact, the abject object is a threat to the person's unified self. This article will apply Kristeva's concept of abjection to Kate Chopin's The Awakening in order to reflect on Edna Pontellier and the abject that she expels in order to shape her independent subjectivity.

\section{Analysis}

Robert Duschinsky describes Kristeva's abjection as 'evocative and vast in scope' as it "promises profound insight on a range of important topics: the construction of identity; the operation of language; the meaning of negative emotions; the psychology of phobia; horror narratives as a literary genre; the repudiation and oppression of outsiders; violence against women, interalia." (2013, p. 710). Pertaining to the scope of this study, our application of Kristeva's abjection focuses on the self-identity of the protagonist in Kate Chopin's The Awakening, Edna Pontellier.

As highlighted by Kristeva, abjection is "the loss of distinction between subject and object or between self and other" (Felluga, 2011). With regard to this confusion and uncertainty about the subject and object, this analysis is divided into two sections: 1) the first part looks at how Edna perceives and is perceived by others, and 2) the second focuses on how 
Edna strives to gain subjectivity over her own self, thus revealing the ambivalence of Edna's perception of herself as a subject on her own or as the object of others, and displaying Edna as a character fails in her attempt at abjection.

\section{Edna Pontellier's Search for Subjectivity and Individuality}

Edna Pontellier is narrated throughout the novel as a married woman with a husband, children and, seemingly, a perfect household: a nice house with servants to help her with her the domestic chores. Furthermore, she is surrounded by a nice circle of friends who occasionally host parties, socialize and generally mingle with each other. Though the picture seems perfect on the surface, Edna believes that her life is the other way round. When the ladies get together at parties or meet up, they imply that Mr Pontellier is "the best husband in the world" and she is "forced to admit that she knew of none better" (Walker 26). And from this point on, we can see that there is some ambiguity in Edna's perceptions of her own life, particularly her marriage and specifically love.

As the narration progresses, Edna is revealed to be having love affairs with other men as well. As if the idea of her thinking about other men is not controversial enough, Edna is actually involved in relationships with two other men: Robert Lebrun and Alcée Arobin. Interestingly, Edna's perceptions and attitudes are different towards all three men. In the first few pages of The Awakening, we can already sense Mr Pontellier's conventional way of treating his wife. For him, Edna is like a possession, an object. Once afternoon when Edna is swimming in the sea, Mr Pontellier voices his discontent at her demeanour and says that she is ““'[b]urnt beyond recognition,"... looking at his wife as one looks at a valuable piece of personal property which has suffered some damage" (Walker 21). Apart from that, Mr Pontellier also uncompromisingly expects Edna to be the perfect housewife: a sensible wife and a loving mother. However, when Edna refuses to look after Raoul who has fever symptoms, Mr Pontellier "reproaches" Edna for her:

...inattention, her habitual neglect of the children. If it was not a mother's place to look after children, whose on earth was it? He himself had his hands full with his brokerage business. He could not be in two places at once; making a living for his family on the street, and staying at home to see that no harm befell them.(Walker24)

Thus far, with his huge expectations and severe criticism of her, Edna finds herself crying without solid ground.

She could not have told why she was crying. Such experiences as the foregoing were not uncommon in her married life. They seemed never before to have weighed much against the abundance of her husband's kindness and a uniform devotion which had come to be tacit and selfunderstood. An indescribable oppression, which seemed to generate in some unfamiliar part of her consciousness, filled her whole being with a vague anguish. (Walker 24)

Later in the novel, Edna attempts to impose her own decision-making on her household. She goes out of the house occasionally without informing Mr Pontellier. She says that she "simply felt like going out. And I went out" and Mr Pontellier seems to be "appeased" by her response (Walker 70). And this small act of defiance can be seen as an effort on her part to become a subject on her own instead of always submitting to Mr Pontellier. But Mr Pontellier rebukes her by leaving the dining table, feigning being upset about the burnt dinner, Edna finds herself deeply affected by it. After dinner, Edna starts to have an emotional breakdown. She throws away her ring and tries to crush it, but to no avail. And thus:

In a sweeping passion she seized a glass vase from the table and flung it upon the tiles of the hearth. She wanted to destroy something. The crash and clatter were what she wanted to hear. (Walker 72)

Earlier, she adopted a nonchalant manner towards Mr Pontellier; she might have felt a small recovery in herself, but as she realises the effect Mr Pontellier has on her, she loses her control over herself again; as Kristeva puts it, the abject is neither object nor subject (Anderson, 2007).

As her relationship with Mr Pontellier is more like an unwritten contract between husband and wife, Edna discovers that she truly loves Robert Lebrun. Different from the obligatory role as Mrs Pontellier, Edna's love towards Robert is raw and not oppressive. She first realizes that she loves Robert when he leaves for Mexico. His departure leavesa void in her soul.

For the first time she recognized anew the symptoms of infatuation which she had felt incipiently as a child, as a girl in her earliest teens, and later as a young woman. The recognition did not lessen the reality, the poignancy of the revelation by any suggestion or promise of instability... . (Walker64-5)

As she acknowledges her feelings towards Robert, Edna displays an abject quality whereby she "recognizes her foundational want" (Anderson, 2007). As she continues to be lovesick, her actions at home are described as "incomprehensible" (Walker 91). Even her father voices his disapproval to Mr Pontellier, saying that he is being "too lenient" and that Mr Pontellier should "put his foot down and hard", as it is the only way to "manage a wife" (Walker 92). 
While Mr Pontellier and Robert are absent, Edna makes the acquaintance with Alcee Arobin who fancies Edna, at first she reproaches him for his interest in her, out of respect for her feelings towards Robert, though not her husband. However, as her marriage to Mr Pontellier is "without love" and Robert is away in Mexico, she discovers that Arobin's feelings for her "acted like a narcotic upon her" (Walker98). On one occasion, Edna and Arobin kiss, and Edna describes it as "the first kiss of her life to which her nature had really responded. It was a flaming torch that kindled desire" (Walker 104). Ironically, a few hours before she kissed Arobin, Edna confessed for the first time that she was truly in love with Robert to Mademoiselle Reisz. After her disclosure, she is in such a happy mood that she writes a "charming letter" (Walker102) to her husband and this eventually leads her to kiss Arobin on the lips. Her attitudes exhibit an abject quality as the love of her life disturbs her identity, whether she wants to be a loyal wife to $\mathrm{Mr}$ Pontellier, a passionate lover to Robert or toy with Arobin's feelings. As Kristeva puts it, the abject is something that does not respect limits and positions (Behler, 2007).

However, the overwhelming control over herself and the men in her life turn to turmoil and subside almost immediately upon Robert's return. Opposite to her fantasy, she finds that Robert is cold and "reserved" (Walker 124). And again, her earlier triumph is quickly overtaken by despondency. As the realization kicks in, Edna:

...[a]nswered her husband with friendly evasiveness, - not with any fixed design to mislead him, only because all sense of reality had gone out of her life; she had abandoned herself to Fate, and waited the consequences with indifference. To Arobin's note she made no reply. (Chopin 125)

Robert continuously disappoints her as he does not come to see her anymore; it turns out later that Robert refuses to go against the social norm.

Love can be paralleled to abjection because both share the same features: suffering and invisibility. That is why love is difficult to fathom much less describe although throughout the centuries there has been so much written on love. (Ali, 2013, p. 13)

This uncommitted manner has crushes Edna's fantasy of gaining herself through the achievement of love. And so, again, Edna's attempt to regain herself and achieve individuality through love fails. Therefore, Edna's search for love has turned her into a subject failing at abjection.

\section{Edna Pontellier's Awakened Individuality}

As aforementioned, in The Awakening, Kate Chopin directly focuses on issues of sexuality and women's selfhood, which were considered groundbreaking topics in the late nineteenth century, even though "Chopin was considered as a writer of sex fiction" (Corse 139). As married women had no rights over property, it was unacceptable to ask for rights over their bodies. Therefore, Chopin violated the norms of society by devoting her novel to these two taboo themes.

Throughout history, women's place has been at home, their role to be a mother and a wife. Later, some feminist movements changed this ideology, but by the time Chopin wrote The Awakening, the social rules opposed women's individuality. In late nineteenth century, women were still expected to get married, submit to their husband sexually and obey him. As a result of blind obedience and submission, women did not have any sense of self or identity. Chopin wrote The Awakening and created Edna Pontellier as a woman searching for her sense of self, thus challenging the social norms. In The Awakening, Chopin tests the limits of freedom for women (Bloom 68). As Edna struggles to gain an independent identity, she questions patriarchal authority. Edna gains self-awareness "through physical awareness" (Walker 178), as through the novel, the reader recognizes that her love for Robert opens up a new horizon of her understanding of self.

Edna seeks to challenge the barriers which have restricted her all these years but she cannot succeed on her path as the patriarchal ideology does not permit her to gain her individuality. As a revolutionary woman, Edna does not intend to obey her husband any more. As a married woman, Edna is expected to be submissive to her husband as her identity is defined by him. That is the main reason why when Edna seeks to shape her identity, the patriarchal system stands in her way. Edna does not intend to follow the traditional expectations of women; and at the same time, society does not allow her to find her own voice.

In The Awakening, Edna tries very hard to reject all the traditions and barriers which have restricted her, but as an individual she cannot overcome the old-fashioned traditions which have been carved in people's minds for eons. The patriarchal system is not willing to accept women's recognition of self as it can be question men's manhood. Edna tries her best to throw off all the roles expected of her as mother and wife, but she fails.

Moreover, one can notice that, throughout the novel, Edna embraces her sexual needs and intends to fulfil them; however, given late nineteenth-century ideology, women should not display sexual desire. She discovers that her needs and desires have been neglected for years. Edna's display of her sexuality emphasizes how far she challenges the patriarchal ideology and how she is crushed by the same society. As a good woman should sacrifice herself for her husband and her family, Edna intends to follow her needs and wishes, even though they are against her husband and family's wishes. Over the years, Edna has been selfless and her identity defined by her rich husband, but now she seeks individuality. 
Edna is not satisfied with her married life as her identity is defined by her husband, and he considers her to be one of his belongings. She is suffering in her husband's house as she needs some space for herself, to seek her individuality. Edna intends to learn how to swim and this desire makes her courageous.

A feeling of exultation overtook her, as if some power of significant import had been given her to control the working of her body and her soul. She grew daring and reckless, overestimating her strength. She wanted to swim far out, where no woman had swum before. (Walker46)

Learning to swim offers freedom, a sense of self and independence to Edna, and this skill can be considered as how she intends to show her strength and power. Unlike many women who do not swim far, she intends to go farther and farther. Even in her social life, she goes beyond the norms as later on she rejects her husband and her children. When Mr Pontellier asks her to enter the house as it is night time and late, she states "do not wait for me" (Walker49). Unlike in the past when she obeyed her husband immediately, now she claims a need to spend some time outside and she is firm in her response. Even when Mr Pontellier brought a glass of wine for her, "she did not wish any" (Walker50). She intends to follow her desires and no one can impose anything on her any more. Edna is not even able to leave the house for a while without first asking permission. When she left the house once, her husband said to her, "I hope you left some suitable excuse" (Walker70), as if without his permission she can do nothing.

As her marriage tormented her, Edna took off her ring and "flung it upon the carpet" (72). If the subject intends to gain his independent subjectivity, "he drives [all the abject things] out, dominated by the drive as he is, and constitutes his own territory, edged by the abject" (Kristeva 6). Here, Edna wants to rid herself of her married life and all it brings. And as she intends to gain her individuality, she asks to spend some time alone. "'Oh! I don't know. Let me alone; you bother me.' It sometimes entered Mr. Pontellier's mind to wonder if his wife were not growing a little unbalanced mentally. He could see plainly that she was not herself" (77). Mr Pontellier does not understand his wife's needs as, within patriarchal society, women's needs are neither defined nor respected. In patriarchal societies, women exist as "vessels of maternity and sexuality with little opportunity for individuality" (Gray 53). One can also notice that Edna and Mr Pontellier's marriage is based on obligations, and this obligation determined that Mr Pontellier "was the husband and master while Edna was the wife and subordinate" (Schade 16), and a master never cares about his slave's condition. Moreover, when a woman starts to know herself and seek some privacy, she is considered mad. Edna intends to leave her husband's house, as "it never seemed like mine, any way- like home" (Walker100). The house is not part of the borders of her subjectivity; therefore, she excludes it. Besides, "her quest for independence, culminating in her move to small house of her own rented with the proceeds gained from betting and the sale of her paintings" (Beer 93). Edna paints whatever interests her and one of the critics of her paintings notices that, little by little, her painting "grows in force and individuality" (Walker100). Based on Kristeva, art is the "only 'know- how' where phobia is concerned" (378); and in her paintings, Edna shows her fear of independence and her movement toward individuality. As she intends to gain self- recognition, her paintings reflect this sense of individuality as well. She is tired of the home which is not her home, and so "without even waiting for answer from her husband regarding his opinion or wishes in the matter, Edna hastened her preparations for quitting her home on Esplanade Street and moving into the little house around the block" (Walker104-5). She decides on her own life and controls it herself, she does not let anyone interfere in her life any more.

In the novel, the reader perceives that Edna falls in love with Robert who was first her friend. As Edna is a married woman, Robert leaves the Island, but after receiving the news that Edna lives in another house, he returns and Edna explains that, "I'm no longer one of Mr. Pontellier's possessions to dispose of or not" (129). She has rejected her husband as he stole her identity during all those years. She adds, "I give myself where I choose. If he were to say, 'here, Robert, take her and be happy; she is yours,' I should laugh at you both" (Walker129). She is just getting rid of a relationship that has restricted her all these years and she is not going to commit to a new one, although she loves Robert and admits that it was Robert who awoke her "last summer out of a life- long stupid dream" (Walker130). "Edna whose life is quiet comfortable materially, is awakened to her need to affirm individual, spiritual freedom" (Yonogi 128). After meeting Robert, Edna recognized her needs and tries to fulfil them as much as she can. In this novel, Chopin acts in a revolutionary way by depicting marriage as an institution which dominates women (Muhammad 86). Edna is determined to have her subjectivity; as a result, "she said to Adele Ratignolle that she would give up all the unessential" (Walker136), she rejects and throws away all that is abject.

As she feels free, without all those imposed obligations and duties, she takes off her clothes and becomes naked. In the nineteenth century, women were not supposed to show their neck, let alone be naked, "how strange and awful it seemed to stands naked under the sky!" (Walker136).And by taking off her clothes, she also excludes the tradition of a dress code for women. As she moved toward the sea, "she thought of Leonce and the children. They were part of her life. But they need to have thought that they could possess her, body and soul" (Walker137). She wanted to define the borders of her subjectivity to reach her individuality, I.

But society was against it. As Edna comes to the realisation that her needs and desires will not be met and fulfilled by the ideologies of her society, she drowns herself, finally to get rid of all those traditions which rob her of her subjectivity. The eventually self-destructive actions of Edna are similar to Shakespeare's Ophelia in Hamlet. 
Ophelia's characterization by Shakespeare has turned into a model for the analysis of girls' susceptibility to sexual exploitation and their eventual self-destructive behaviour. (Safaei and Hashim, 2013, p. 186)

One can notice that Edna drowns herself and it is the representation of "a beautiful women in a state of over discontent" (Harmon 54). She gains her subjectivity by defining her borders, but her life has a tragic ending as she cannot be an independent woman in a society which does not offer any sense of independence to women but asks them to submit themselves to their husbands. Edna moves from point A to point B in the course of the story; but as she pulled towards point $\mathrm{C}$, she fails as society stops her (Robert 228-9). Then, the reader notices that the novel has two philosophical dimensions, the quest for self and tragedy (Ito 8).

\section{Conclusion}

All in all, Edna Pontellier comes to realise that her identity has been erased by the patriarchal ideology that prioritises men's needs and ignores women's subjectivity. As a result, Edna intends to reject whatever is abject and to define her borders of "I". She rejects her husband, her marriage ring and her children, even her clothes, and submits herself to the waves of the sea as her desire to be independent and to assert her individuality are not respected by society. She gains knowledge of selfhood, but this knowledge leads her to her death.

\section{References}

Ali, H. M. (2013). The Abject Lover of the Courtly Love Era. 3L: The Southeast Asian Journal of English Language Studies, 19(3), 11-19.

Anderson, X. (2007). Summary of "Approaching Abjection" by Kristeva.

Bai, L. (2014). The Re-understanding of Edna Pontellier's Death. Theory and Practice in Language Studies,845-9.

Beer, J. (2008). The Cambridge Companion to Kate Chopin. New York: Cambridge University Press.

Bloom, H. (2008). Bloom's Guide: Kate Chopin's The Awakening. New York: Infobase Publishing.

Corse, S. M. and Davis W. S. (2002). Gender and Literary Valorization: The Awakening of a Canonical Novel. Sociological Perspectives 45(2), 139-61.ProQuest.

Gray, J. B. (2004). The Escape of the "Sea": Ideology and the Awakening. Southern Literary Journal 37(1), 53-73. ProQuest.

Harmon, Ch. (1998). Abysses of Solitude: Acting Naturally in Vogue and the Awakening. College Literature 25(3), 5266. ProQuest.

Ito, F. (1999). A Quest for Self and Love: Two Philosophical Dimensions of Edna's Struggle Toward Self-Fulfillment and its Tragic Consequence in "the Awakening". Order No. 1417093 The University of Mississippi. Ann Arbor: ProQuest. Web. 19 October 2014.

Kristeva, J. (1982). Powers of Horror, an Essay on Abjection. New York: Colombia University Press. Print.

Muhammad, S. H. (2001). Voices of Disobedience in the Fiction of Charlotte Perkins Gilman, K. Ch., Edith Wh., Nella L., and Mary A. Order No. 3025056 Indiana University of Pennsylvania. Ann Arbor: ProQuest. Web. 19 October 2014.

Parvulescu, A. (2005). To Die Laughing or to Laugh at Dying: Revisiting The Awakening. New Literary History, $477-$ 98.

Platizky, R. (1995). Chopin's The Awakening. The Explicator, 99-102.

Powell, T. (2009). Chopin's The Awakening. Haldref Publication, 278-9.

Robert, L. M. (1998). Beyond the Love Triangle: Trios in the Awakening. The Midwest Quarterly, 39(2), 22834.ProQuest.Web. 19 October 2014.

Safaei, M., \& Hashim, R. S. (2013). Ophelia Transformed: Revisioning Shakespeare's Hamlet . GEMA Online ${ }^{\circledR}$ Journal of Language Studies, 181-91.

Schade, J. J. (2004). The Inevitability of Failure: Edna Pontellier's Pursuit of Self in Kate Chopin's "the Awakening"." Order No. 1419710 Roosevelt University. Ann Arbor: ProQuest.

Walker, N. A. (1993). The Awakening Kate Chopin. New York: Bedford Books of St. Martin's Press.

Yonogi, R. (1989). The Struggle Towards Self-Fulfillmentin Comparative Perspective: The Theme of Woman's Awakening in Three Realist Novels - Gustave Flaubert's "Madame Bovary", Kate Chopin's "the Awakening", and Arishima Takeo's "Aru Onna"." Order No. 9011084 University of Illinois at Urbana-Champaign. Ann Arbor: ProQuest. Web. 19 October 2014. 